\title{
IPTEKS PENGENDALIAN INTERN ASET TETAP PADA PT. PLN (PERSERO) UP3 MANADO
}

\author{
Ireyne Regina Gerung ${ }^{1}$, Winston Pontoh $^{2}$ \\ ${ }^{1,2}$ Jurusan Akuntansi, Fakultas Ekonomi dan Bisnis Universitas Sam Ratulangi, J1. Kampus Unsrat, Manado, \\ 95115, Indonesia \\ Email : ireynegerung@yahoo.com
}

\begin{abstract}
In carrying out all its operational activities, a company needs and has never been separated from the role of fixed assets. Fixed assets are one of the assets of a company that has a useful life of more than one year and has a large materiality value. At PT. PLN (Persero) UP3 Manado, fixed assets are one of the assets with a very large value of materiality. Therefore, it takes a control of fixed assets to maintain and secure fixed assets from possible errors, both recording errors and policies made on fixed assets themselves. PT. PLN (Persero) UP3 Manado Certainly has a variety of fixed assets that support all company activities. Internal control of fixed assets at PT. PLN (Persero) UP3 Manado has been running well. PT. PLN (Persero) UP3 Manado is very concerned about the elements in the control of inter-fixed assets. Even though he has performed his duties well, PT. PLN (Persero) UP3 Manado still must pay attention to all the elements that exist to avoid things that are detrimental to the company in this case PT. PLN (Persero) UP3 Manado.
\end{abstract}

Keywords : fix assets, intern control.

\section{PENDAHULUAN}

Aset tetap adalah aset yang memiliki wujud atau tangible aset yang diperlukan atau dimiliki oleh setiap perusahaan untuk membantu setiap usaha proses operasional dalam suatu perusahaan yang tentunya tidak untuk dijual ataupun dilepas dan mempunyai masa atau jangka waktu pemakaian lebih dari 2 tahun. Aset tetap adalah aset yang dapat dilihat dan mempunyai bentuk fisik dengan masa pemakaian atau kegunaan yang panjang. Setiap perusahaan yang mempunya aset tetap diperoleh dengan cara dibeli secara tunai, kredit ataupun pertukaran. Dengan demikian, pengendalian intern aset tetap sangat dibutuhkan sebagai tolak ukur darui seriap aset tetap atau aset tetap yang ada dalam suatu perusahaan. Dengan adanya pengendalian intern aset tetap bertujuan untuk menjaga data-data pribadi perusahaan, meneliti data akuntansi, serta mematuhi kebijakan-kebijakan manajemen perusahaan yang yang ada dalam perusahaan.

Dengan pengendalian intern aset tetap atau aset tetap yang baik, pihak manajemen perusahaan akan sangat terbantu dalam hal pengawasan setiap aset tetap yang ada dalam perushaan, serta dapat meningkatkan produktivitas karyawan dengan memanfaatkan aset tetap yang ada secara efektif dan efisien. PT. PLN (Persero) merupakan perusahan BUMN yang pastinya juga memiliki berbagai macam aset tetap.

\section{TINJAUAN PUSTAKA}

Pengendalian Internal. Dikutip dari Dinapoli (2010), menyebutkan bahwa pengendalian intern merupakan suatu proses yang dilakukan perusahaan untuk dapat meyakinkan bahwa operasi akan berjalan berdasarkan tujuan yang telah ditentukan. Menurut Valery G. Kumaat (2011:15), Pengendalian Intern adalah bagaimana cara memberikan arahan, pengawasan dan pengukuran semua aset tetap yang ada dalam suatu perusahaan. Sangat penting bagi perusahaan untuk menghindari penyalahgunaan serta melindungi semua 
aset yang ada di dalam perusahaan. Menurut Krismiaji (2010:218), Pengendalian Intern merupakan rencana perusahaan serta cara yang digunakan untuk melindungi aset yang ada dalam perusahaan agar dapat memberikan informasi benar adanya. Menurut Sukrisno Agoes (2008:79), Pengendalian Intern merupakan kegiatan yang dilakukan oleh perusahaan yang bertujuan untuk memberikan kepastian terhadap pencapaian suatu perusahaan.

Tujuan Pengendalian Internal. Dikutip dari Danang Sunyoto (2014:157), menyebutkan pengendalian internal terdiri dari strategi perusahaan yang disiapkan untuk memberikan kejelasan bagi perusahaan, bahwa tujuan dan sasaran perusahaan telah tercapai. Menurut Mulyadi (2010:163), pengendalian intern bertujuan untuk menjaga keamanan aset yang dimiliki perusahaan, meneliti kebenaran data-data akuntansi perusahaan, memaksimalkan keefisiensiensi dalam operasional perusahaan dan mendorong agar mematuhi semua kebijakan-kebijakan manajemen yang ada dalam perusahaan.

Aset Tetap. Dikutip dari Suhayati (2009:68), menyebutkan bahwa aset tetap merupakan aset yang diperlukan oleh perusahaan dalam menjalankan aktivitas operasional perusahaan dan bersifat relatif tetap atau jangka pemakaian yang lama. Menurut Rudianto (2009:272), aset tetap merupakan sesuatu yang memiliki wujud yanf dimiliki perusahaan yang bersifat permanen yang digunakan untuk semua kegiatan perusahaan. Menurut Kasmir (2008:39), aset tetap merupakan aset berharga milik perusahaan yang digunakan perusahaan dalam jangka waktu yang lama. Aset tetap dibagi menjadi dua macam, yaitu aset tetap yang berwujud dan aset tetap yang tidak berwujud. Menurut Soepriyanto (2010:2), aset tetap merupakan aset yang dapat digunakan dalam waktu yang lama. Aset tetap ini tidak untuk dijual karena merupakan bagian yang digunakan untuk menjalankan operasioal perusahaan.

Komponen Pengendalian Internal Committee of Supporting Organization of the Tredway Commission (COSO). Menurut Azhar Susanto (2013:96), mengatakan Sistem pengendalian internal berhubungan dengan aktivitas operasional perusahaan dengan alasan bisnis yang mendasar. Pengendalian internal akan berjalan dengan baik apanila pengendalian tersebut terorganisir dengan dengan fasilitas yang merupakan bagian penting bagi suatu perusahaan. Pengendalian internal yang terorganisir memicu meningkatnya kualitas, menghindari biaya yang tidak perlu dan mengahasilkan respon yang baik terhadap perubahan keadaan. Menurut Hery (2013:90), Kerangka kerja pengendalian intern yang digunakan oleh sebagian besar perusahaan A.S dikeluarkan oleh Committee of sponsoring organizations (COSO). Komponen pengendalian intern $C O S O$, meliputi : (1) lingkungan pengendalian; (2) penilaian resiko; (3) aktivitas pengendalian; (4) informasi dan komunikasi; dan (5) pemantauan.

\section{METODE DAN PENERAPAN IPTEKS}

\subsection{Metode Penerapan Ipteks}

Metode ipteks yang digunakan yaitu penerapan pengendalian intern aset tetap yang efektif menurut COSO.

\subsection{Teknik Penerapan Ipteks}

Teknik ipteks yang diterapkan adalah penerapan pengendalian intern aset tetap menurut COSO.

\section{PEMBAHASAN}

\subsection{Gambaran objek pengendalian intern aset tetap}

Pada tahun 1900-an, Perusahaan Belanda mendirikan beberapa pembangkit tenaga listrik yang hanya diperuntukan keperluan pribadi. Berawal dari hal tersebut, kemudian berkembang dan dipakai untuk kepentingan umum. Perusahaan listrik belanda tersebut bernama NV.NIGM kemudian mereka memperluas usahanya dari gas ke tenaga listrik. Pada tanggal 17 Agustus 1945, perusahaan listrik yang ada di indonesia direbut oleh para Pemuda Indonesia dan diserahkan pada Pemerintah Republik Indonesia pada bulan September 1945. 
Pada Tahun 1972, Pemerintah Indonesia menetapkan status Perusahaan Listrik Negara (PLN) sebagai perusahaan yang bergerak dalam bidang listrik, serta ditetapkan sebagai pemegang kuasa dalam hal usaha ketenagalistrikan. Pemerintah memberikan kesempatan kepada investor yang ingin bergerak dalam usaha penyediaan tenaga listrik pada tahun 1992. berdasarkan keputusan tersebut, PLN dialihkan menjadi perusahaan perseroan (Persero) pada bulan juni tahun 1992.

PT. PLN (Persero) merupakan perusahaan yang negara yang beroperasi dalam hal kelistrikan di Republik Indonesai yang berkedudukan di Jakarta. PT. PLN (Persero) memiliki unit-unit kelompok diantaranya: Unit Distribusi, Unit Transmisi, Unit Penyaluran dan Pusat Pengaturan Beban, Unit Pembangkitan, Unit Wilayah, Unit Induk Proyek, dan Unit Penunjang. PT. PLN (Persero) menetapkan metode pembayaran pascabayar, dimana konsumen bisa menggunakan listrik terlebih dahulu kemudian pihak PLN akan mendatangi rumah dan mengecek meter kemudian menetapkan harga yang akan dibayar oleh konsumen. Pada tahun 2010, PT. PLN (Persero) mengeluarkan kebijakan baru yang disertai dengan produk baru yang dikenal dengan nama listrik pintar. Kebijakan yang baru ini menggunakan metode pembayaran prabayar, dimana konsumen harus membayar dimuka atau membeli token listrik terlebih dahulu agar bisa menggunakan listrik. Akan tetapi, PT. PLN (Persero) tidak mewajibkan untuk menggunakan metode prabayar, melainkan pilihan kepada konsumen untuk memilih metode apa yang akan digunakan.

Pengendalian Intern aset Tetap Pada PT. PLN (Persero) UP3 Manado. Struktur organiasi PT. PLN (Persero) UP3 Manado berbentuk 4 lini yaitu bagian jaringan, transaksi energi listrik, pelayanan dan administrasi, dan perencanaan. aset tetap yang dibeli diotorisasi oleh manajer UP3 kemudian dilakukan penganggaran oleh bagian keuangan. Perbaikan aset tetap diotorisasi oleh bagian pengadaan dan manajer UP3. PT. PLN (Persero) UP 3 Manado mengakui salah satu beban perusahaan terletak pada pemeliharaan dan perbaikan aset tetap yang ada di perusahaan.

\subsection{Pembahasan}

PT. PLN (Persero) UP3 Manado harus memperhatikan 5 unsur pengendalian menurut COSO antara lain :

1. Lingkungan pengendalian. Dalam lingkungan pengendalian perusahaan harus menetapkan corak suatu perusahaan seperti: Perusahaan harus terlebih dahulu menetapkan tujuan perusahaan, agar segala sesuatu yang dilaksanakan bisa terarah. Perusahaan terlebih dahulu harus ada falsafah dan filosofih perusahaan. Perusahaan harus menetapkan praktek dan kebijakan karyawan yang sesuai misalkan kebijakan dan praktik pembinaan SDM yang berhubungan dengan aset tetap, perusahaan harus memberikan training dengan waktu yang memadai minimal 3 bulan. Perusahaan harus menetapkan struktur organisasi yang baik sesuai bagian-bagiannya yang tentunya didalam terkait wewenang dan tanggung jawab, sehingga memiliki kerangka kerja sesuai dengan yang diharapkan. Memiliki program pelatihan bagi karyawan sehingga dapat menggunakan semua aset tetap dengan baik serta melakukan pemeriksaan terhadap aset tetap secara rutin.

2. Penilaian risiko. Dalam penilaian resiko perusahaan harus melakukan pengujian nilai aset agar aset tetap yang akan dijual atau dikeluarkan berdasarkan nilai yang sesuai dengan nilai aset yang akan dijual atau dikeluarkan.

3. Aktivitas pengendalian. Dalam aktifitas pengendalian, semua transaksi yang behubungan dengan aset tetap diantaranya pembelian, perbaikan, ataupun pelepasan selalu diotorisasi oleh manajer UP3 hal ini baik adanya mengingat agar supaya tidak terjadi penyalahgunaan wewenang. Perusahaan tidak memberikan tanda atau nomor disetiap aset tetap yang ada, hal ini dapat berpengaruh apabila ada aset tetap yang hilang, perusahaan akan sulit untuk mendeteksi aset tetap yang hilang tersebut. Perusahaan melakukan 
pencocokan aset tetap dengan daftar aset tetap yang akan dibeli sehingga dapat mencegah terjadinya penyelewengan dan penggelapan dalam perusahaan.

4. Informasi dan komunikasi. Dalam informasi dan komunikasi perusahaan memiliki informasi dan komunikasi yang baik dan akurat terhadap keberadaan aset tetap yang ada dalam perusahaan.

5. Pemantauan. Dalam pemantauan, perusahaan sudah melakukan pemantauan dengan baik atau sudah terorganisisr. Perusahaan mengawasi setiap aktivitas aset tetap di setiap prosesnya, mulai dari penganggaran aset tetap yang akan dibeli, pengendalian aset tetap hingga proses pelepasan atau pengeluaran aset tetap.

\section{KESIMPULAN DAN SARAN}

\subsection{Kesimpulan}

Pengendalian intern aset tetap pada PT. PLN (Persero) UP3 Manado telah berjalan dengan baik. PT. PLN (Persero) UP3 Manado sangat memperhatikan unsur-unsur dalam pengendalian inter aset tetap diantaranya, lingkungan pengendalian, penilaian resiko, aktivitas pengendalian, informasi dan komunikasi, serta pemantauan.

\subsection{Saran}

Meskipun telah melaksanakan tugas dengan baik, PT. PLN (Persero) UP3 Manado tetap harus memperhatikan semua unsur-unsur yang ada untuk menghindari hal-hal yang merugikan bagi perusahaan dalam hal ini PT. PLN (Persero) UP3 Manado.

\section{DAFTAR PUSTAKA}

Dinapoli, T. 2010. Responsibilitas Manajemen Terhadap Pengendalian Internal, Division of Local Goverment and School Accountability, New York.

Hery. 2014. Akuntansi Aset, Liabilitas, dan Ekuitas. PT. Gramedia Widiasarana Indonesia. Jakarta.

Kasmir . 2008. Analisis Laporan Keuangan. Raja Grafiindo Persada. Jakarta

Krismiaji. 2010. Sistem Informasi Akuntansi. UPP AMP YPKN. Yogakarta.

Kumaat, V. 2011. Internal Audit. Penerbit Erlangga. Jakarta.

Messier, dkk. 2009. Jasa Audit \& Jaminan Pendekatan Sistematis. Salemba Empat. Jakarta

Rudianto. 2009. Pengantar Akuntansi. Erlangga. Jakarta.

Susanto, A. 2013. Sistem Informasi Akuntansi. Lingga Jaya. Bandung

Suhayati, E 2009 . Auditing Konsep dasar dan Pedoman Pemeriksaan Akuntan Publik : Graha Ilmu. Yogyakarta.

Sunyoto, D. 2014. Auditing Pemeriksaan Akuntansi. Center of Academic Publishing Service. Yogyakarta.

Soepriyanto. 2010. Pengantar Akuntansi. Salemba Empat. Jakarta.

Sukrisno, A. 2008. Auditing Pemeriksaan Oleh Kantor Akuntan Publik Jilid Satu. Lembaga Penerbit Fakultass Ekonomi Universitas Padjajaran. Jakarta. 